\title{
DISCRICIONARIEDADE ADMINISTRATIVA E RESPONSABILIDADE DECISÓRIA: Uma Leitura Contemporânea
}

\author{
http://dx.doi.org/10.21527/2176-6622.2019.52.125-142
}

Recebido em: 21/2/2019

Aceito em: 7/7/2019

\section{José Eduardo Ribeiro Balera}

Bacharelado em Direito (2013) e Mestrado em Filosofia (concentração em Ética e Filosofia Política, 2016) pela Universidade Estadual de Londrina. Mestrado em Ciência Jurídica pela Universidade Estadual do Norte do Paraná (2018). Especialista em Direito Público pela Faculdade Damásio de Jesus (2015). Especialista em Filosofia e Teoria do Direito pela Pontifícia Universidade Católica de Minas Gerais (PUC/MG). Especialista em Direito do Estado pela Universidade Estadual de Londrina (2015). Colaborador dos Projetos de Pesquisa: Habermas, Rawls e MacIntyre: um debate entre neo-kantianos e neo-aristotélicos; Estudos Foucaultianos; Acesso à Justiça: a instrumentalidade do processo frente à Jurisdição. Tem experiência em Direito Público, Direito do Trabalho, Filosofia Política e do Direito. É advogado e professor universitário. http://lattes.cnpq.br/7986665214511225. j.ribeirobalera@gmail.com

\section{RESUMO}

O surgimento e o fortalecimento do Estado de Direito impuseram, a partir do substrato normativo constitucional, balizas ao agir dos indivíduos em sociedade, ao próprio aparato estatal e aos seus administradores. Assim, a Administração Pública, dotada de prerrogativas, é incumbida do atingimento de resultados coletivamente relevantes e desejados. Neste cenário, o presente trabalho tem por objetivo analisar o espaço da discricionariedade administrativa ante as exigências de correção decisória, em especial pelo rigorismo imposto pela teoria hermenêutica jurídica contemporânea. Inicialmente, apresenta-se o entendimento consolidado na dogmática jurídica acerca da discricionariedade e seus pontos de divergência. Em seguida expõe-se a relação entre a atividade interpretativa e o agir discricionário, segundo a doutrina administrativista. Em continuidade ao estudo sistemático deste instituto jurídico, examina-se as diferentes espécies de discricionariedade e suas potenciais fragilidades. Por fim, são pormenorizadas as críticas advindas da hermenêutica contemporânea em razão do direito fundamental à resposta correta ou "verdadeira".

Palavras-chave: Discricionariedade administrativa. Liberdade decisória. Interpretação. Correção decisória. Controle jurisdicional.

ADMINISTRATIVE DISCRETION AND DECISION-MAKING RESPONSIBILITY: A CONTEMPORARY ANALYSIS

\section{ABSTRACT}

The emergence and strengthening of the Democratic State of Law have imposed, from the constitutional normative substrate, signposts for the individuals' actions in society, the State Apparatus and its administrators. Endowed with prerogatives, the Public Administration is therefore charged with achieving the collectively relevant and desired results. Considering this scenario, the objective of this work is to analyze the range of the administrative discretion in the face of decision-making demands, particularly the rigor imposed by the contemporary legal hermeneutic theory. Initially, the understanding consolidated in the legal dogmatic about discretion and its aspects of divergence are presented. Then, one exposes the relation between the interpretative activity and the discretionary act, according to the administrative doctrine. Following the systematic study of this legal institute, one examines the different sorts of discretion as well as their potential fragilities. Finally, the critiques of contemporary hermeneutics are thoroughly presented in reason of the fundamental right to a correct or "true" response.

Keywords: Administrative discretion. Freedom of decision. Interpretation. Correct decision. Judicial control.

\section{SUMÁRIO}

1 Introdução. 2 A Obediência ao Estado e a Imposição de Limites Legais: A Relação entre Administrados e Administração Pública. 2.10 Exercício da Discricionariedade pela Administração Pública e seus Limites Segundo a Dogmática Jurídica. 2.2 Disposição Normativa, Interpretação e Discricionariedade. 2.3 Espécies de Discricionariedade Administrativa. 3 Uma Proposta Contemporânea: A Incompatibilidade da Atuação Discricionária em Relação ao Estado Democrático de Direito. 4 Conclusão. 5 Referências. 


\section{Direito:

\section{INTRODUÇÃO}

Diferentes razões podem ser elencadas como justificativas à obediência dos indivíduos ao Estado e as suas deliberações. Em contraposição, a este também não é concedida, como demonstrou a História, a ampla e total liberdade na escolha das soluções que atenderão aos interesses da coletividade.

As prerrogativas da Administração Pública permitem o atingimento de resultados que dificilmente poderiam ser obtidos e gozados, individualmente ou em pequenos grupos, pelos cidadãos em sua vida em sociedade. Isto não legitima, contudo, toda e qualquer decisão da Administração, ao contrário, impõe maiores responsabilidades e a necessidade de inserção de instrumentos para seu controle.

Diante disto, o presente trabalho tem por objetivo analisar o espaço decisório da Administração a partir do instituto da discricionariedade administrativa diante da teoria hermenêutica contemporânea, por exemplo, de Ronald Dworkin. Em outros termos, pretende-se examinar a extensão decisória da Administração perante as exigências impostas ao processo interpretativo de fenômenos juridicamente relevantes.

Para tanto, inicialmente, delineia-se o contexto no qual a Administração Pública está inserida, isto é, a conjuntura legalista e limitadora do Estado Democrático de Direito. Em seguida apresenta-se o estado da arte quanto ao tema da discricionariedade, quer dizer, o modo que a dogmática jurídica tem delimitado o agir discricionário na esfera administrativa, bem como as divergências que persistem.

Para a continuidade desta investigação resgata-se a classificação estabelecida por Georges Abboud, revelando-se as peculiaridades do instituto e as fragilidades de cada uma de suas facetas. Estes primeiros pontos de vulnerabilidade permitem o desenvolvimento de objeções que são trazidas na sequência, a partir da teoria hermenêutica, por exemplo, o direito fundamental à resposta correta e a maior abertura ao controle jurisdicional do mérito dos atos administrativos.

Embora seja de predominância teórica e com aportes filosóficos, a investigação mostra-se relevante ao crescimento de uma cultura jurídica mais exigente no âmbito do Direito Administrativo, em prol da averiguação e do controle do cumprimento das obrigações pela Administração Pública e distanciada das perspectivas que favoreçam o uso temerário e pessoal dos recursos públicos, muitas vezes blindados do exame de mérito pelo poder Judiciário.

\section{A OBEDIÊNCIA AO ESTADO E A IMPOSIÇÃO DE LIMITES LEGAIS: A Relação Entre Administrados e Administração Pública}

Ao longo da História, os pensadores da filosofia política e do Direito arquitetaram diferentes explicações quanto à essencialidade da criação do Estado e dos motivos pelos quais os indivíduos em sociedade sujeitam-se aos comandos e à ordem jurídica estatal. Para Hobbes (1979), por exemplo, a vida do homem no estado de natureza é marcada pela luta em busca da sobrevivência. Destarte, a passagem à sociedade civil, por meio do contrato social, é justamente a garantia do cumprimento dos pactos e a abolição do cenário geral de guerra e da violência. Para Locke (2003), o Estado surge com a função de garantir a tutela de direitos e também de resolução de conflitos, visto que a disputa e as contendas seriam inevitáveis, inexistindo um terceiro imparcial, no estado de natureza, à solução de tais inconvenientes.

Em Lectures of Jurisprudence, o positivista John Austin (1911) entende uma íntima relação entre o direito e a coerção, pois a constituição de obrigações jurídicas decorreria da habitual sujeição às ordens de um soberano. Hart (1994), por sua vez, defende que a existência do direito estaria diretamente relacionada a fontes sociais, o direito seria constituído por regras primárias (delimitadoras de condutas) e secundárias (quanto ao reconhecimento de regras primárias, a sua alteração e até mesmo em relação a sua aplicação) e tais as regras jurídicas não se confundiriam com ordens meramente coercitivas. ${ }^{1}$

\footnotetext{
Seria possível diferenciar entre ser obrigado e ter uma obrigação. A mera ameaça ou coerção por um comando não é o elemento definidor do direito em Hart, embora tenha certa importância na teoria de Austin. Conforme a tese hartiana, pode ocorrer a obediência a uma ordem coercitiva, por exemplo, de um assaltante, mas esta não será, necessariamente, uma regra jurídica.
} 
Estas perspectivas, conquanto sucintas, revelam a importância adquirida pelo aparato estatal e pelo Direito, com impacto direto sobre a vida de cada indivíduo em meio ao convívio social. Mesmo que as normas quanto às funções administrativas do Estado já existissem, inseridas no jus civile, somente em meio ao contexto revolucionário, entre o fim do século 18 e primórdios do século 19, que foi possível o estabelecimento de um ambiente fértil ao desenvolvimento do conceito de Estado de Direito e de balizas ao exercício das prerrogativas e imposição de limites à atuação dos governantes (DI PIETRO, 2016, p. 1-2).

Sem embargo, como destaca Martins (2014, p. 201-205), é possível observar distintos paradigmas na compreensão da relação entre Administração e administrados: (i) no Estado Liberal, entende-se a tutela formal da autonomia privada diante das interferências estadistas como suficiente, ao considerar a liberdade dentro da própria dinâmica de mercado; (ii) no Estado Social, enfatiza-se o substrato da isonomia em sentido social e político e almeja-se o incremento da equiparação material; (iii) no Estado Democrático de Direito, objetiva-se aprimorar esta relação, com a superação de obstáculos presentes nos modelos anteriores, por exemplo, o "paternalismo" do Estado social e a tensão entre autonomia pública e privada. Cumpre ressaltar, porém, que o modelo burocrático pouco a pouco entra em crise com o Estado Social e o formato gerencial passa a sucedê-lo. Termos referentes à saúde e à assistência pública, por exemplo, deixam de ser questões de preocupação exclusiva do Estado, pois tais responsabilidades são transferidas "às organizações da sociedade civil organizada, mantendo uma espécie de controle por intermédio de contratos de gestão" (MARTINS, 2014, p. 213).

Este recorte evidencia a complexidade da atuação estatal e, por consequência, a faceta ambivalente da Administração, visto que é possuidora de prerrogativas em favor da concretização de interesses coletivos e, concomitantemente, sujeita-se a grandes imposições e controles. Com o Estado Constitucional de Direito, como recorda Abboud (2011), a partir dos ensinamentos de Garcia Herrera, a legalidade aplicada ao poder público tem dúplice expressividade: (i) seu aspecto formal subordina-o aos comandos mais gerais e abstratos da lei; (ii) enquanto, segundo a perspectiva substancial, exige-se dos três poderes o seu exercício em garantia e em tutela dos direitos fundamentais, posto que "constituem prerrogativas que asseguram diversas posições jurídicas ao cidadão, ao mesmo tempo em que constituem limites/restrições à atuação do Estado" (ABBOUD, 2011, p. 64).

Diante disto, é essencial delinear o espaço admissível de decisão pela Administração Pública. Para Justen Filho (2013, p. 240), a disciplina da discricionariedade passou a ser uma questão central no âmbito do Direito Administrativo ante a evolução democrática da concepção de Estado, afinal, em um Estado autoritário tal conceito seria inexistente e toda escolha e consequente imposição seriam regidas pela vontade daquele que possui o poder de fato.

Divergindo da doutrina tradicional, Ommati $(2013$, p. 27) defende que a emergência do Direito Administrativo não se deu em prol da efetivação do Direito Constitucional e das limitações trazidas por este, mas "como mecanismo de manutenção das práticas de poder do antigo regime". Embora, trivialmente, exprima-se o sentido liberal atribuído ao Direito Administrativo, ou seja, limitador do Estado e garantidor dos direitos fundamentais dos particulares, especialmente a propriedade, o histórico brasileiro, como revelado por Sergio Buarque de Holanda (1995) e Raymundo Faoro (1998), esteve comprometido pelas práticas patrimonialistas, isto é, "a Administração Pública brasileira sempre foi vista como a continuidade da casa do dono do poder do momento" (OMMATI, 2013, p. 29). Abboud (2014, p. 123), seguindo Enterría, compreende uma proximidade do instituto da discricionariedade em relação ao gubernaculum, ${ }^{2}$ diante de sua intangibilidade pelo controle jurisdicional.

Isto posto, é preciso compreender como a dogmática administrativista tem tratado o referido instituto, bem como as perspectivas e as exigências conduzidas pela hermenêutica contemporânea.

\footnotetext{
2 Na definição de Abboud (2014, p. 102, itálico no original): “[...] era um poder, ainda que não contra legem, que não precisava prestar contas a ninguém, uma vez que inexistiria qualquer padrão normativo que pudesse avaliar a correção do ato do Rei, determinado em regime de gubernaculum".
} 


\section{Debate}

\subsection{O Exercício da Discricionariedade pela Administração Pública e seus Limites Segundo a Dogmática Jurídica ${ }^{3}$}

A discricionariedade é, muitas vezes, entendida como um poder concedido pela lei à Administração, pois não é possível a previsão do expediente necessário e mais vantajoso à coletividade diante da diversidade de casuísmos. Neste sentido, Hely Lopes Meirelles (2011, p. 173) entende este instituto como uma faculdade pela qual "a Administração pode praticar com liberdade de escolha de seu conteúdo, de seu destinatário, de sua conveniência, de sua oportunidade e do modo de sua realização". Apesar disso, seriam discricionários tão somente os meios elegíveis pela Administração, mas nunca os fins a serem alcançados.

Para Furtado (2013, p. 526), a discricionariedade não pode ser considerada um poder atribuído à Administração Pública, posto que os termos "vinculado" e "discricionário" refletem uma tradição, mas que não é repetida propriamente por correção técnica, pois os poderes administrativos implicam o "exercício de prerrogativas" com interferência no âmbito individual, com a imposição de encargos, sanções ou outras culminações; por outro lado, o poder discricionário ou vinculado não importa no necessário exercício de tais prerrogativas. ${ }^{4}$

A confusão decorre da proximidade do exercício dos poderes administrativos (hierárquico, disciplinar, regulamentar e de polícia) com os conceitos de atividade administrativa vinculada e discricionária. A hipótese de aplicação de sanção ao servidor público é um dos exemplos trazidos pela doutrina para melhor esclarecimento desta relação, pois o ordenamento outorga, muitas vezes, certo grau de liberdade ao administrador para definição da penalidade a ser imposta, logicamente de acordo com o ato praticado e o caso em concreto no âmbito do exercício do poder hierárquico, não obstante, em outras ocasiões, o seu exercício é vinculado, como o observado pelo artigo 132 da Lei 8.112/90. Nesse sentido, conclui Furtado (2013, p. 527, itálico no original), a discricionariedade administrativa seria "a liberdade conferida pela lei ao administrador público para a adoção da melhor solução para o caso concreto". O grande problema desta compreensão é conferi-la à qualidade de "um direito subjetivo de natureza privada" (JUSTEN FILHO, 2013, p. 242, itálico no original).

Diferentemente de Hely Lopes Meirelles, que define a discricionariedade como verdadeiro poder em abstrato da Administração, Marçal Justen Filho (2013) entende o mesmo instituto como uma disciplina normativa que tem por objeto as atividades administrativas do Estado e pela qual se exige a apuração de alguns elementos tendo em vista o caso concreto. Dessarte, nas hipóteses em que os preceitos jurídicos restringem "a autonomia de escolha da autoridade administrativa, há vinculação; ${ }^{5}$ quando a norma cria intencionalmente margem de autonomia, há discricionariedade" (JUSTEN FILHO, 2013, p. 242). Cumpre ressaltar que não existe ato totalmente discricionário, afinal, esta liberdade só pode ser exercida segundo as balizas legais (BANDEIRA DE MELLO, 2008, p. 424).

No mesmo sentido, Di Pietro (2016, p. 254) afirma a existência de "certa margem de liberdade de decisão diante do caso concreto" autorizado pela lei, logo, a escolha dar-se-á diante da pluralidade de soluções igualmente válidas. Haveria, ao menos, dois critérios para sua justificação, um de natureza jurídica e outro de ordem prática. Para o primeiro, referencia-se a ideia kelseniana da elaboração do Direito por degraus, pois seria a discricionariedade a viabilizadora dos acréscimos, em cada grau, de elementos inovadores, com ponto de partida a norma de maior grau (no caso, a constitucional), seguido pelas leis, regulamentos, até sua aplicação no fato em concreto. Quanto ao segundo fundamento (o prático), elide-se o automatismo na aplicação legal e minimiza-se as consequências advindas da impossibilidade de preestabelecimento pelo legislador de todos

\footnotetext{
${ }^{3}$ Não se trata de interpretações finais, absolutas e estáticas acerca do fenômeno jurídico e até mesmo da conduta social, mas do trabalho sistematizado e apropriado à compreensão do cenário existente, inclusive, no âmbito do pensamento jurídico. Esclarece Adeodato (2007, p. 143): "[...] A dogmática jurídica consiste justamente na sistematização e no manejo das regras que garantem que esses processos de revisão e atualização permanecerão dentro dos limites fixados pelas próprias normas jurídicas, estabelecendo modos interpretativos e integradores para a adaptação da norma ao fato".

${ }^{4}$ Nas palavras de Furtado (2013, p. 526): “Não negamos, é evidente, a existência de atividades vinculadas e discricionárias. Negamos, ao contrário, que o simples fato de determinada atividade administrativa ser discricionária (quando exercida pelo administrador público em razão da liberdade conferida por lei para a definição do conteúdo dos atos a serem praticados) ou vinculada (o que se verifica quando a atividade está totalmente definida em lei, inclusive quanto ao conteúdo dos atos administrativos dela decorrentes) importe em exercício de prerrogativa pública. Ao exercer uma prerrogativa, a Administração Pública, ao contrário, define o comportamento de particulares ou de agentes públicos, aplica sanções ou restringe o exercício de direitos e de atividades".

5 Maria Sylvia Zanella Di Pietro (2016, p. 254) vai além quanto à caracterização dos atos vinculados e defende que, além de inexistirem outras opções à Administração em razão dos requisitos e dos limites legalmente previstos, surge um direito subjetivo pelo qual o particular pode exigir de determinada autoridade pública a realização de tal ato e sujeito à sindicabilidade jurisdicional.
} 
os cenários de atuação do administrador, diante das imensuráveis e crescentes necessidades e demandas coletivas, afinal, a "dinâmica do interesse público exige flexibilidade de atuação, com a qual pode revelar-se incompatível ao moroso procedimento de elaboração das leis" (DI PIETRO, 2016, p. 255).

Vale lembrar que a ausência de diplomas legais não implica a origem de qualquer abertura à discricionariedade. Esta, contudo, não deve servir de justificativa para a não concretização de direitos fundamentais, afinal, a própria Constituição é o fundamento normativo a sua concretização e a eles deve-se garantir uma eficácia mínima. ${ }^{6} \mathrm{Na}$ condição de prerrogativa de valoração concedida aos agentes administrativos, a discricionariedade possibilita a eleição da melhor conduta que atenda aos interesses coletivos ou denominados públicos. Tem-se, desta maneira, sua efetivação no instante da prática do ato, ${ }^{7}$ como também em momento posterior, quando se decide pela sua revogação (CARVALHO FILHO, 2013, p. 51). Não obstante, ela não se confunde com a arbitrariedade, pois deve estar fundada em princípios da boa administração, como a eficiência, a imparcialidade e a tutela da legalidade, inclusive passível de contestação pela coletividade ou mesmo por via do Judiciário.

Ao se considerar os elementos do ato administrativo, há sempre vinculação quanto ao sujeito. A forma, em geral, é vinculada, exceto quando a lei admite uma diversidade de modos para sua prática. Quanto à finalidade, há vinculação quando considerada em sentido restrito, mas se admite a discricionariedade em relação à finalidade ampla. ${ }^{8}$ No que tange ao motivo, a discricionariedade pode decorrer: (i) da omissão legal ou (ii) da utilização de "vocábulos plurissignificativos", também denominados de conceitos jurídicos indeterminados (DI PIETRO, 2016, p. 257-258).

Desta última observação emergem algumas divergências relevantes a serem consideradas: Haveria alguma relação entre a atividade interpretativa e o surgimento da discricionariedade? Seria uma liberdade intencionalmente concedida ou também decorrente da estrutura atécnica na produção legislativa?

\subsection{Disposição Normativa, Interpretação e Discricionariedade}

Não se pode negar que a atividade de aplicação do Direito implica, inevitavelmente, a "contribuição criativa" do intérprete e, em alguns casos, revela inovações relevantes diante do texto normativo. Esta, entretanto, não se confunde com o poder-dever atribuído por lei ao administrador na análise das circunstâncias do caso ao atingimento de determinadas finalidades. Enquanto na interpretação almeja-se a explicitação da "vontade legislativa que é determinada pelo sistema jurídico em si", a discricionariedade legitima juridicamente a vontade do aplicador (JUSTEN FILHO, 2013, p. 243-244). A qualidade insatisfatória da redação legislativa, a textura aberta da linguagem ou até mesmo a adoção de conceitos ultrapassados e anacrônicos pelo legislador não podem justificar a atuação discricionária do administrador.

Há que se reconhecer, todavia, a impossibilidade de previsão de regras a todos os casos e a marcante insuficiência da linguagem jurídica. Diante disto, Hart reconhece a textura aberta do Direito e a necessidade de as autoridades, administrativas e judiciais, decidirem a forma adequada à resolução das contendas, observando-se as circunstâncias e os interesses em conflito, isto é, situações em que atuarão discricionariamente. Como destaca Herbert L. A. Hart (1994, p. 127, tradução livre),

A discricionariedade, portanto, deixada pela linguagem pode ser muito ampla; de modo que, se ele [a autoridade pública ou judicial] aplica a regra, a conclusão, mesmo que ela não possa ser arbitrária ou irracional, é a disposição de uma escolha. Ele escolhe pela inclusão de um novo caso em uma linha de casos por causa das semelhanças que possam ser defendidas, razoavelmente, tanto juridicamente relevante como suficientemente

\footnotetext{
${ }^{6}$ A crítica surge às denominadas "normas programáticas", por definir fins almejados, justificando-se a atuação no processo legiferante. A omissão do legislador, todavia, não pode servir de obstáculo à concretização dos preceitos e das ordens constitucionais, inclusive, definidoras de "tarefas". Como ensina Canotilho (1999, p. 1.051, itálico no original): "todas as normas são actuais, isto é, têm uma força normativa independente do acto de transformação legislativa", ou seja, as disposições constitucionais não são meras declarações, mas todas devem ter seu valor normativo e com conteúdo definido em concreto e mesmo com alcance específico em cada caso.

7 Como ressalta Fernanda Marinela (2011, p. 254), tecnicamente o ato não é discricionário, pois "a liberdade está no exercício da competência e não efetivamente na prática do ato".

${ }^{8}$ A finalidade ampla é o interesse público, afinal, o regime jurídico administrativista é marcado pela supremacia do interesse público e almejando o atingimento das necessidades da coletividade. A finalidade restrita, por sua vez, refere-se aos resultados e desfechos singulares delineados pela lei, seja de maneira implícita ou explícita.
} 


\section{Debate}

próxima. No caso das normas legais, os critérios de relevância e a proximidade da semelhança dependem de muitos fatores complexos que funcionam através do sistema legal e sobre os objetivos ou propósitos que podem ser atribuídos à regra.

Para Hart (1994, p. 136), na condição de integrante do viés do positivismo jurídico, ${ }^{9}$ todo ordenamento jurídico deixa um grande espaço em aberto à atuação discricionária de tribunais e demais autoridades para resolver incertezas de seus estatutos e de suas leis, além do desenvolvimento de qualificações únicas manifestadas pelos seus precedentes.

No contexto da teoria positivista contemporânea, Luigi Ferrajoli (2013, p. 70-75) sustenta uma distinção entre a discricionariedade de caráter político ou administrativo e a de cunho judicial. A primeira seria inerente às funções do governo e legislativa. A segunda estaria atrelada à atividade interpretativa, às possibilidades de decidibilidade da verdade processual, à potencial probabilidade da verdade fática e ao cunho discutível da verdade para o Direito. Além deste primeiro elemento, a judicial seria mais restrita, pois está vinculada à "aplicação substancial da lei", ou melhor, "se manifesta unicamente nas decisões interpretativas [...] relativas ao 'significado' das normas aplicáveis, começando pelos direitos constitucionalmente estabelecidos" (FERRAJOLI, 2013, p. 75). A discricionariedade política cria novos direitos nos limites constitucionais e, neste aspecto, não se trata de vinculação, mas limitação das normas de sua produção. O pensador italiano vai além ao defender que possuem fontes de legitimação distintas, dado que a discricionariedade política estaria legitimada pelo fundamento da representação e a judicial na sujeição à lei com o objetivo de dizer o Direito. Nas palavras do autor: "Se trata de dos tipos de discrecionalidad profundamente distintos, que remiten a las dos fuentes de legitimación a su vez distintas y diferenciadas en los [...]: la representación política para la legis-lación y la sujeción a la ley para la juris-dicción" (FERRAJOLI, 2013, p. 74).

A diferenciação, estabelecida por Ferrajoli, parece evidenciar componentes implícitos considerados pela doutrina, como se fosse possível a instituição de métodos distintos de trabalhar com o Direito de acordo com a esfera de poder a qual pertença o seu operador, fato que é, no mínimo, arriscado e capaz de distribuir o ônus operacional de maneira assimétrica e constituir espaços de atuação totalmente variáveis, com um Judiciário contido e uma ampla esfera de decidibilidade ao Legislativo e ao Executivo.

Segundo Di Pietro (2016, p. 256), é possível o surgimento da discricionariedade por três espaços de apreciação consentidos pela lei: (i) quando a legislação atribui, expressamente, à Administração tal margem de liberdade, por exemplo, nas remoções de servidores ex office; (ii) por omissão legal, via aplicação do substrato principiológico do Direito, em virtude das limitações de previsão do legislador; e (iii) da delimitação de competências sem objetivar a conduta esperada. Nesse contexto, o uso de conceitos jurídicos indeterminados causa polêmica. A doutrina majoritária tem entendido que sua adoção representa abertura ao agir discricionário da Administração, desde que sejam "conceitos de valor". A corrente doutrinária oposta, todavia, compreende que se trataria de um espaço à atividade interpretativa para a obtenção de uma única solução (DI PIETRO, 2016, p. 258).

Em sentido distinto, de acordo com Justen Filho (2013, p. 246-248), há pelo menos três técnicas legislativas de transferência de margem de autonomia ao aplicador do Direito sem implicar discricionariedade: (i) a adoção de conceitos técnicos-científicos: momento em que a ciência e a técnica indicarão ao aplicador a medida apropriada a ser tomada, ou seja, trata-se da abertura às alternativas decorrentes do conhecimento científico, devendo esclarecer os fundamentos da escolha de tal opção; (ii) o uso de conceitos jurídicos indeterminados: na verdade, seu conteúdo é determinável e delimitável ao caso concreto, contudo não exato, viabilizando sua aplicação caso a caso, isto é, não há autonomia na deliberação da solução ao atingimento de determinado fim e sim na abrangência conceitual; (iii) o emprego de conceitos valorativos: não se confunde

\footnotetext{
${ }_{9}^{9}$ Como esclarece Rafael Simioni (2011, p. 211): “Naturalmente, no âmbito do positivismo jurídico, não é possível demonstrar que existem respostas corretas, porque o positivismo vê o direito como uma questão semântica que pergunta se um caso concreto se encaixa ou não se encaixa na descrição contida nos textos jurídicos". Mesmo Kelsen (2003), em sua Teoria Pura do Direito, faz referência à decisão discricionária no Direito, visto que o intérprete define o sentido da norma no ordenamento, logicamente, tendo em vista a moldura existente.
} 
com o conceito jurídico indeterminado, pois este "envolve um juízo de conhecimento sobre os fatos, enquanto o conceito valorativo exige juízos de valor", ou melhor, os juízos vigentes em determinado momento histórico de uma sociedade. ${ }^{10}$

Para Carvalho Filho (2013, p. 56), a confusão surge por não possuírem padrões claros de conduta, com uma notória distinção: os conceitos jurídicos indeterminados possuem previsão normativa e os efeitos derivados de sua ocorrência estão estabelecidos também no texto normativo; a discricionariedade, por sua vez, possui maior abrangência no processo deliberativo pelo órgão administrativo, pois este amoldará também seus efeitos.

Como ressalta Eros Roberto Grau (2016, p. 160), porém, os conceitos, na condição de ideias universais, não podem ser passíveis de indeterminação, na verdade os termos e as expressões que são indeterminados. Explica o autor que

[...] são tidos como "indeterminados" os "conceitos" cujos termos são ambíguos ou imprecisos - especialmente imprecisos - razão pela qual necessitam ser complementados por quem os aplique. Neste sentido, são eles referidos como "conceitos" carentes de preenchimento com dados extraídos da realidade. Os parâmetros para tal preenchimento - quando se trate de conceito aberto por imprecisão - devem ser buscados na realidade, inclusive, na consideração das concepções políticas predominantes. [...] Quando se trate de conceito aberto por ambiguidade, seu preenchimento é procedido também mediante a consideração do contexto em que inserido - o que, de qualquer forma, não deve obscurecer a verificação de que, sempre, é da participação no jogo de linguagem no qual inserido o termo do conceito que decorre a possibilidade de o compreendermos, procedendo ao seu preenchimento. [...] ainda que ambíguas ou imprecisas, as palavras e expressões jurídicas (= os termos dos conceitos) expressam significações sempre determináveis (GRAU, 2016, p. 160-161).

Ainda que a sua relação com os conceitos indeterminados seja questionada por parte da doutrina, a prática da discricionariedade deve observar alguns limites, entre os quais: (i) a adequação - a concatenação entre a opção eleita e a finalidade legal - e (ii) a aferição dos elementos motivadores - a impossibilidade de análise dos fundamentos motivadores, seja de fato e de direito, da decisão ou a incongruência entre eles conduz, quando menos, à apreensão de vícios como a má aplicação do poder discricionário ou mesmo o desvio de finalidade, embora seja inevitável a existência de um espaço de escolha, inclusive de ordem técnica.

Diferentemente das atividades vinculadas, as quais se submetem a critérios legais para sua integral execução e, por consequência, torna-se viável a sua avaliação quanto à validade, a doutrina tem destacado a impossibilidade de o Judiciário adentrar no mérito do ato discricionário, ou seja, quanto à valoração da conveniência e oportunidade, pois a tutela jurisdicional estaria restrita ao controle de legalidade e da observância dos limites de seu exercício. Segundo esta visão, o exame dar-se-ia por três mecanismos: (i) os limites do poder e a correspondência com as finalidades legalmente pretendidas; (ii) os motivos determinantes e (iii) a compatibilidade aos princípios jurídicos.

A primeira está diretamente relacionada à margem deliberativa legalmente concedida, em outros termos, se não foi utilizada pela autoridade pública para a obtenção de um resultado distinto do preceituado pela lei (o denominado desvio do poder). Como salienta Furtado (2013, p. 209, itálico no original), no desvio do poder ou "desvio de finalidade não se faz necessária a presença de qualquer outro elemento invalidante, como a violação dos princípios da moralidade ou da impessoalidade; basta que a finalidade do ato seja incompativel com o interesse público". Logo, a necessidade de anulação e os vícios no agir podem surgir na hipótese de inexistência da relação de correspondência entre os objetivos imediatos do ato e na efetivação do interesse público.

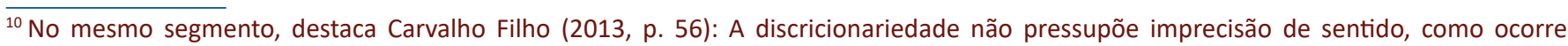
nos conceitos jurídicos indeterminados, mas, ao contrário, espelha a situação jurídica diante do qual o administrador pode optar por uma dentre várias condutas lícitas e possíveis. Aqui é própria norma que, ao ser criada, oferece ao aplicador a oportunidade de fazer a subsunção do fato à hipótese normativa mediante processo de escolha, considerando necessariamente o fim a que se destina a norma. Não é, portanto, uma opção absolutamente livre, visto que tem como parâmetro de legitimidade o objetivo colimado na norma. A fisionomia jurídica da discricionariedade comporta três elementos: (1) norma de previsão aberta que exija complemento de aplicação; (2) margem de livre decisão, quanto à conveniência à oportunidade da conduta administrativa; (3) ponderação valorativa de interesses concorrentes, com prevalência do que melhor atender ao fim da norma."
} 
Quanto ao segundo mecanismo, como reforça Hely Lopes Meirelles (2011, p. 202, itálico no original), a "teoria dos motivos determinantes funda-se na consideração de que os atos administrativos, quando tiverem sua prática motivada, ficam vinculados aos motivos expostos, para todos os efeitos jurídicos". Logo, mesmo em atos discricionários, haveria a possibilidade de avaliação da conformidade e da relação entre os motivos fundamentais do ato e da realidade, caso contrário aquele deve ser considerado inválido. Pelo fato de esta perspectiva ser doutrinária, todavia, o Judiciário não poderá considerar como válido o ato em razão de fundamentos distintos dos explicitados pela Administração. Segundo Di Pietro (2016, p. 263, negrito do original), o exame dos motivos engloba "os pressupostos de fato e as provas de sua ocorrência".

A congruência aos princípios jurídicos representa a concepção mais atual e talvez mais sensível ao mérito administrativo. Com o maior reconhecimento da Constituição e de sua força normativa, ${ }^{11}$ em especial por seus princípios fundamentais, o controle não se reduz à mera formalidade dos atos, mas a sua afinidade aos preceitos fundamentais do ordenamento. Nesse sentido, embora a conveniência e a oportunidade sejam blindadas por um discurso tradicional, inevitavelmente a prévia análise de sua consistência normativa gera uma apreciação tangencial do mérito do ato. Abboud (2014, p. 120), a partir da doutrina alemã, resgata que "o uso da discricionariedade será ilegítimo, juridicamente inválido, sempre que forem violados os princípios constitucionais e outros princípios jurídicos, como os direitos de liberdade, de igualdade e de proporcionalidade". Segundo a perspectiva de Luís Roberto Barroso (2001, p. 33-34), dentro da teoria constitucional, os princípios traduzem o núcleo de valores acolhidos por determinado ordenamento jurídico, refletindo ideologias da sociedade, além de suas premissas basilares e suas metas. Possuem uma função importante de proporcionar harmonia e coesão ao ordenamento, minimizando tensões normativas.

Apesar disso, este controle reflete um risco potencialmente paradoxal, pois a utilização dos princípios pode retratar um avanço à tutela da integridade sistêmica do ordenamento ou mesmo à interferência arbitrária dos poderes em bases de um decisionismo acrítico. O princípio da moralidade pode servir de exemplo, afinal, confunde-se a guarda da moralidade prestigiada juridicamente com a ética, as distintas perspectivas de bem viver e a moralidade em sentido mais amplo. Certamente a moralidade deve ser entendida de acordo com os valores políticos consagrados na história de uma sociedade, pois o seu substrato não é o mesmo em todas as ordens jurídicas, isto é, ecoa as experiências, os avanços e as conquistas da história particularizada de uma comunidade. ${ }^{12}$

Dentro desta temática surgem as divergências quanto ao controle e à efetivação de políticas públicas, em especial via a adoção da denominada judicialização da política ou ativismo judicial, uma vez que as limitações dos administradores equivalem-se, em certo grau, às vivenciadas pelos magistrados, observando-se que estes, muitas vezes, sofrem com o desamparo técnico, minimamente necessário à avaliação holística do Direito no âmbito das práticas da Administração.

\subsection{Espécies de Discricionariedade Administrativa}

Conquanto, habitualmente, os atos administrativos sejam apreendidos e classificados a partir das margens decisórias facultadas pelas disposições legais, para Georges Abboud (2014) há possibilidade de ordenação do instituto da discricionariedade em cinco grupos: (i) a interpretativa, (ii) a optativa, (iii) a performática, (iv) a volitiva e (v) a técnica. Não obstante, esta divisão pode ser compreendida como suas distintas facetas, dado que a identificação de determinada característica, sua aproximação ou pertencimento à categoria específica não conduzirá, necessariamente, à exclusão de outra. Pelo contrário, garantirá um estudo sistemático e esclarecedor das fragilidades, ordinariamente ignoradas e que exigem uma alteração de pensamento e de postura técnica.

\footnotetext{
${ }^{11}$ Entende-se por força normativa o "caráter vinculativo e obrigatório de suas disposições, superada a fase em que era tratada como um conjunto de aspirações políticas e uma convocação à atuação dos poderes públicos" (BARROSO, 2001, p. 42).

12 Como explica Di Pietro (2016, p. 264): “Não cabe ao magistrado substituir os valores morais do administrador público pelos seus próprios valores, desde que uns e outros sejam admissíveis como válidos dentro da sociedade; o que ele pode e deve invalidar são os atos que, pelos padrões do homem comum, atentam manifestamente contra a moralidade. Não é possível estabelecer regras objetivas para orientar a atitude do juiz. Normalmente, os atos imorais são acompanhados de grande clamor público, até hoje sem sensibilizar a Administração. Espera-se que o Judiciário se mostre sensível a esses reclamos".
} 
A primeira abordagem ou agrupamento conceitual, a denominada discricionariedade interpretativa, funda-se no espaço de liberdade concedido à Administração pela lei, ou seja, leva à costumeira distinção entre atos discricionários e vinculados. Por esta concepção, a decisão de ordem vinculada decorreria de um "processo lógico-subsuntivo da aplicação da lei" (ABBOUD, 2014, p. 127). Ou seja, enquanto o ato vinculado decorreria da estrita subsunção aos critérios e às definições legais, a atuação discricionária não identificaria os parâmetros para sua concretização, em razão da abertura permissiva legal propiciada à mensuração dos motivos e do objeto do ato a ser praticado, isto é, a seu juízo de conveniência (os benefícios e as vantagens) e de oportunidade (momento adequado) em sua prática. Neste viés, estaria inclusa a perspectiva de Celso Antônio Bandeira de Mello e com consequências importantes no que tange às possibilidades de controle de tais atos pelo poder Judiciário, posto que existiriam obstáculos à avaliação do mérito e, consequentemente, na invalidação do ato em razão do objeto ou motivo, embora fosse possível o exame de outros elementos, como a competência, a forma, a finalidade e sua manifestação (ABBOUD, 2014, p. 128). Segundo esta visão, a ampliação da margem de escolha induz a um espaço da discricionariedade, pois a resposta não está expressamente prevista no instrumento legal.

Aparentemente esta perspectiva estabelece métodos diferenciados de solução de acordo com o enquadramento do ato, se forem "casos fáceis" e previsíveis tratar-se-ia de mera combinação lógica concretizada por atos vinculados; se a Administração deparar-se com "casos difíceis", estes seriam hipóteses de agir de modo discricionário. Muitas críticas decorrem desta visão. Abboud (2014, p. 129), por exemplo, considera-a defasada, pois aposta "na subsunção e na possibilidade de pré-fabricar normas prontas para o caso concreto". Para José Emílio Medauar Ommati (2013), trata-se de uma definição contraditória que ignora o giro hermenêutico oportunizado pela Filosofia, como se a atuação deliberativa estivesse dissociada da atividade interpretativa. Nas palavras do autor:

Desde Gadamer, se sabe que toda atividade de compreensão envolve também a interpretação e a aplicação (decisão). [...] entender que exista objetividade desvinculada de escolhas subjetivas não se sustenta mais. A atividade hermenêutica pressupõe compreensão, interpretação e aplicação em um todo unitário, de modo que o intérprete possa colocar seus preconceitos em jogo, em diálogo com as demais pré-compreensões, a partir de uma determinada tradição.

Assim, entender que o ato vinculado é aquele em que não há margem de escolha da Administração é desconhecer que todo processo de aplicação é tão de interpretação e compreensão e, portanto, imantado de pré-compreensões, de subjetividade (OMMATI, 2013, p. 33).

Logo, revela-se um empecilho nas bases hermenêuticas, pois a relevância da linguagem tornou-se explícita e um componente essencial à compreensão do fenômeno jurídico, inclusive quanto às possibilidades da constatação de verdades em sua esfera de conhecimento.

O segundo tipo nominado de discricionariedade administrativa optativa, no que lhe concerne, focaliza na pluralidade de respostas ou soluções às mesmas questões, ou seja, o agir discricionário está diretamente relacionado à diversidade de opções a serem consideradas pela Administração e, sob tal justificativa, "parcela da doutrina chega a afirmar que a eleição de alternativas igualmente válidas, essência do conceito de discricionariedade, é outorgada por normas jurídicas que atuam como pressuposto [...] mas também como limite" (ABBOUD, 2014, p. 131-132).

Os limites a tais atos seriam os princípios gerais de Direito e, consequentemente, seu controle estaria acentuadamente abalado, pois somente seria viável sua avaliação pelo Judiciário quando observadas notórias irregularidades ou desproporcionalidades. ${ }^{13}$

\footnotetext{
${ }^{13}$ Abboud demonstra especial preocupação com esta forma de compreender a discricionariedade, pois acaba por esvaziar ainda mais as possibilidades de controle do ato administrativo e a busca pela tutela via Judiciário. O exemplo de discricionariedade optativa trazido pelo autor é o de nomeação de candidatos aprovados em concursos públicos, pois a nomeação ou não é pura expectativa de direito do candidato, sujeito à discricionariedade da Administração. Surgiria o seu direito tão somente se um candidato, fora da ordem de classificação, viesse a ser nomeado, ou seja, contrário a princípios gerais do Direito e da própria lógica de ingresso nas carreiras públicas.
} 
Esta visão, que sustenta a possibilidade de atribuir-se igual valor ${ }^{14}$ a todas as respostas e aos problemas jurídicos (inclusive no âmbito da Administração Pública), reflete uma contradição interna ao próprio caráter ambivalente da interpretação. Afinal, quando se interpreta e se define a resposta juridicamente correta, acaba-se pode considerar todas as outras como inferiores ou inadequadas.

O processo interpretativo é um fenômeno social e pressupõe, caracteristicamente, que determinada conclusão esteja correta ou incorreta, verdadeira ou falsa e que seja, até mesmo, boa ou má (DWORKIN, 2011, 125-126). A reivindicação do domínio único ou do monopólio da verdade poderia parecer , no mínimo, esdrúxula em determinadas ocasiões, por exemplo na explicação de um dispositivo legal diante de tantas outras interpretações desenvolvidas pela doutrina. Semelhantemente, porém, seria surreal ou incomum pressupor a igual validade de todas as abordagens.

Para melhor explicar este fato, em Justice for Hedgehogs Ronald Dworkin traz um exemplo das implicações de tal postura, ou melhor, desvencilhada de qualquer afirmação, mesmo implícita, da verdade ou da única resposta correta no Direito:

[...] Em certas circunstâncias, o ceticismo pareceria não somente estranho como também escandaloso. Imagine um juiz que envia um réu penal para a prisão, ou talvez para o corredor da morte, ou que obriga um réu cível a pagar uma imensa indenização, mas admite no meio da sentença que outras interpretações das leis, que exigiriam decisões contrárias, são tão válidas quanto a sua (DWORKIN, 2014, p. 191). ${ }^{15}$

É imprescindível reconhecer: quando um indivíduo assume determinada opinião e seus fundamentos como os mais apropriados, razoáveis ou mais bem interpretados, fatalmente, acaba por inferiorizar ou ao menos atribuir o caráter de falsidade ou erroneidade às proposições opostas (DWORKIN, 2011, p. 126). Por isso, os indivíduos discordam tanto quanto às conclusões, como também em relação aos métodos para a obtenção de tais conclusões.

Vale lembrar que, diferentemente, de outras áreas, como a científica, que trabalha com conceitos criteriais, a área jurídica (e também política) trabalha com conceitos interpretativos, como a ideia de democracia, igualdade, liberdade, entre outras. Os conceitos criteriais (criterial concepts) têm uma definição em comum pelo uso dos mesmos critérios para distinguir casos específicos. ${ }^{16}$ Os conceitos interpretativos (interpretive concepts) podem ser reconhecidos nas práticas sociais, porém sem concordância exata quanto ao seu caráter, identificando-se algum valor ou desvalor.

Apesar de tudo isso, "a fenomenologia da interpretação como uma atividade que visa caracteristicamente buscar a verdade permanece intacta", parece deixar evidente uma justificativa: "os juízos interpretativos, como os juízos morais, não podem ser independentemente verdadeiros" (DWORKIN, 2014, p. 194-195). ${ }^{17}$

\footnotetext{
${ }^{14} \mathrm{~A}$ tradicional concepção de discricionariedade apresenta grande proximidade à corrente do pragmatismo jurídico, pois acaba por aceitar valores pessoais como fatores influentes no ato de decidir, impondo tão somente a condição de que sejam devidamente atrelados ao suporte empírico. Dentro da teoria da decisão judicial, esta corrente ganha destaque com Richard Posner (1997), pois acredita que há um enriquecimento do pensamento político e da prática política a partir do momento que são introduzidos valores controvertidos em concepções do interesse público. Esclarece o autor a partir da tese pragmatista aplicada às decisões judiciais: "[...] por ahora, baste con advertir que se refiere a que el fundamento de los juicios (sean jurídicos o de otro tipo) ha de encontrarse em sus consecuencias y no en la deducción a partir de premisas al modo de un silogismo" (POSNER, 2011, p. 52).

${ }^{15}$ No texto em inglês: "In some circumstances skepticism would seem not only odd but outrageous. Imagine a judge sending an accused criminal to jail, perhaps to death, or awarding a huge verdict against a civil defendant, and then conceding in the course of his opinion that other interpretations of the law that would have required contrary decisions are just as valid as his own." Cf. DWORKIN, Ronald. Justice for Hedgehogs. Cambridge: Harvard University Press, 2011, p. 125-126.

${ }^{16}$ Dworkin faz uso do conceito de triângulo equilátero, uma vez que se tem critérios bem definidos para o reconhecimento de outros padrões do mesmo triângulo, no caso, o critério seria uma figura geométrica com três lado iguais. Logicamente, o pensador reconhece que a precisão dos critérios do triângulo equilátero não é o mesmo em outros conceitos criteriais, pois podem gerar uma divergência maior.

${ }^{17}$ É interessante que Dworkin distingue um aspecto importante entre juízos morais e sobre o mundo físico, pois aqueles não são independentemente verdadeiros, ou seja, sempre estão dependentes de razões pelas quais permita considerá-los como verdadeiros. Cf. DWORKIN, Ronald. Justice for Hedgehogs. Cambridge: Harvard University Press, 2011, p. 114.
} 
A questão, todavia, agrava-se a partir do momento em que se considera a circularidade, pois "não tenho como verificar a precisão de minhas convicções morais exceto usando outras convicções morais" (DWORKIN, 2014, p. 151). ${ }^{18}$

Em sequência, a discricionariedade performática está diretamente vinculada à "autoblindagem" originada do uso de termos e expressões como interesse público, conveniência e oportunidade. O caráter performativo decorre de uma distinção estabelecida por John Langshaw Austin. De modo diverso da visão tradicional acerca da linguagem, em que esta tem como característica fundamental a natureza descritiva, Austin distingue entre enunciados constatativos e performáticos. Os primeiros relacionam-se a fato, inclusive, quanto a sua representação e descrição. Os performativos, por sua vez, "não constatam fatos ou ações, mas antes eles mesmos executam uma ação, fazem parte de uma operação" (OLIVEIRA, 2006, p. 152). Nas palavras de Austin, esta nomenclatura decorre do termo "executar" (perform) e "indica que a emissão do enunciado é a realização de uma ação - não é normalmente considerado como apenas dizendo algo" (AUSTIN, 1962, p. 7, tradução livre).

A admissão deste recurso acaba por exaurir também o âmbito de controle do próprio Judiciário, como se observa na prática cotidiana, no momento em que as decisões judiciais passam a negar a análise de correção do mérito dos atos administrativos a partir destes conceitos de abrangência ilimitada. Como destaca Georges Abboud (2014, p. 138-139, itálico no original):

Os termos interesse público e conveniência e oportunidade são os enunciados performáticos por excelência no que se refere à discricionariedade. Na maior parte das lides, o Judiciário nega-se a adentrar no mérito do ato administrativo com fundamento em que o ato teria sido pautado em critérios de conveniência e oportunidade. Frise-se: nada mais performático do que essa afirmação: o julgado que diz que o ato administrativo está embasado em critério de conveniência e oportunidade, na realidade, não diz nada, não diz se o ato é ou não legal/constitucional, limita-se apenas a afirmar que se pauta em critério é a de conveniência e oportunidade.

O uso da linguagem performática, contudo, não se trata de uma particularidade do âmbito administrativo, posto que a mera citação de termos como a razoabilidade e a proporcionalidade é, muitas vezes, considerada pelo Judiciário como suficiente para a motivação sem a adequada explicitação dos critérios utilizados, mesmo que a prática e a doutrina alemãs tenham delimitado o apropriado uso do postulado da proporcionalidade. Apesar disso, a aceitação da prática performativa na seara administrativa e a recusa do Judiciário na avaliação dos critérios do ato administrativo, para a devida reputação do caráter legal ou constitucional, são obstáculos para uma maior efetivação do Estado de Direito e da inafastabilidade da tutela jurisdicional (artigo 5o, XXXV, CF).

A quarta modalidade de discricionariedade, intitulada de volitiva, enfatiza o agir intelectual da Administração proporcionado pelo ordenamento, quer dizer, "a arte de escolher o melhor, de apreciar e avaliar todas as coisas, tendo em vista a sua finalidade" (ABBOUD, 2014, p. 146). Este, no entanto, não parece ser um atributo próprio da atuação discricionária, mas inerente a toda aplicação do Direito e, consequentemente, a definição da melhor resposta pela interpretação. Por esta via, prestigia-se o agir que satisfaça a vontade do agente (administrador) e seu juízo de conveniência e oportunidade, na mesma proporção que também seja apreendida como um proceder consonante à vontade da lei.

A "vontade da lei" ou a "intenção da legislação" não podem ser confundidas com os estados mentais ou estados psicológicos dos legisladores. Embora, muitas vezes, alegue-se a "intenção do legislador" como argumento de validação das proposições interpretadas, tem-se denominado como falácia intencional ("intentional" fallacy), pois diferentemente da interpretação conversacional, ${ }^{19}$ a correta interpretação do Direito não é dependente do que os legisladores de determinada época tinham em mente ou mesmo subconscientemente.

\footnotetext{
${ }_{18}$ Para Dworkin (2011, p. 100), o grande problema da circularidade é que o indivíduo sempre fará recurso a outras proposições morais para justificar as anteriores, com a esperança de que este círculo possua um raio maior. Com isso, é possível que indivíduos com percepções completamente distintas não venham a concordar com nenhuma das razões e, embora persista a expectativa de convencê-la, é mais importante demonstrar a atuação com responsabilidade do que a demonstração da veracidade de sua opinião. Cf. DWORKIN, Ronald. Justice for Hedgehogs. Cambridge: Harvard University Press, 2011, p. 100.

${ }^{19}$ Como ensina Dworkin (2011), o interpretar do direito é diferente do científico, pois os objetos de estudo deste último não são criados pelas pessoas, e também diferente da interpretação 'conversacional', uma vez o objeto desta última é o que as pessoas dizem, por exemplo, quando um amigo lhe diz algo e é essencial que se entenda o que ele desejava no momento da fala diretamente direcionada.
} 


\section{Debate}

Nas palavras de Dworkin (2011, p. 129-130, tradução livre):

Mas, quando falam acerca da intenção da lei, eles não podem estar relacionando ao que os legisladores tinham em mente enquanto votaram. Muitos legisladores não entendem as leis que votam, e aqueles que o fazem são tão frequentemente movidos por seus próprios motivos políticos - para agradar eleitores, financiadores, ou líderes do partido - como por quaisquer dos princípios ou projetos políticos que um jurista pode atribuir às leis por eles aprovadas. ${ }^{20}$

Em suma, a adequada interpretação do Direito não é dependente do conhecimento dos estados psicológicos ou o que pensavam os legisladores no processo legislativo, mas da construção linear e responsável pela compreensão do Direito concatenada e coerente aos valores consagrados pelo ordenamento.

A discricionariedade técnica, por último, refere-se ao "poder para atuar com fundamento em critérios fornecidos por saberes especializados, sejam esses saberes derivados de ciências puras ou aplicadas" (ABBOUD, 2014, p. 150), quer dizer, alicerça-se em conhecimentos técnicos no processo decisório. Este instituto gera divergências na doutrina, afinal, o juízo de conveniência e oportunidade seriam mitigados ou, praticamente, inexistentes, pois o critério técnico deve sobressair. Por consequência, a identificação deste critério, cientificamente estruturado e reconhecido, esvazia a margem de liberdade e o espaço de escolha da própria Administração, tendo em vista a máxima eficiência e também o melhor atendimento dos direitos constitucionalmente consagrados.

Neste caso, a lei estabelece referências gerais a serem cumpridas, mas a escolha em concreto estará vinculada aos "juízos técnico-científicos", porém é preciso admitir também que "nenhuma ciência pode gerar aplicações práticas absolutamente precisas, uniformes e destituídas de alternativas ou dúvidas" (JUSTEN FILHO, 2013, p. 257). Em outros termos, ao mesmo tempo que inexiste uma abertura discricionária quanto à conveniência e oportunidade ao administrador na escolha da solução a ser empregada diante das demarcações de natureza técnico-científica, a ciência dificilmente subtrairá a pluralidade de alternativas disponíveis.

\section{UMA PROPOSTA CONTEMPORÂNEA:}

\section{A Incompatibilidade da Atuação Discricionária em Relação ao Estado Democrático de Direito}

Além das críticas e fragilidades já salientadas na seção anterior, a doutrina contemporânea tem buscado novas saídas ao tratamento da discricionariedade administrativa e das respostas juridicamente esperadas, em proveito de uma postura mais rigorosa à prática administrativista e, consequentemente, suscetível de controle pela via jurisdicional e pela população em geral, haja vista o caráter democrático atribuído ao Estado de Direito Moderno.

Por meio do recurso à hermenêutica e à leitura integrada do ordenamento, revelam-se contradições na técnica jurídica. Por exemplo, haveria realmente um espaço de liberdade à Administração? Segundo Celso Antônio Bandeira de Mello (2008), a discricionariedade expressaria justamente um grau de liberdade para a adoção da melhor solução ao fato em concreto e ao atendimento dos fins legais. Embora não a entenda como uma liberdade, Marçal Justen Filho (2013, p. 242) segue próximo à mesma perspectiva, ao defini-la como o "poder-dever de decidir segundo a avaliação da melhor solução para o caso concreto". Para Alexandre Santos de Aragão (2013), trata-se de uma margem de escolha legalmente admitida entre "indiferentes jurídicos".

A tradicional compreensão da discricionariedade administrativa, exposta pela doutrina, reflete o antigo problema de desagregar a discricionariedade da interpretação, como se fosse possível a dissociação desta e a aplicação (OMMATI, 2013, p. 34). Como já explicitado, esta crítica revela a influência do giro linguístico filosófico no âmbito jurídico, pois a linguagem passa a ser condição ao conhecimento. Segundo Luis Henrique Madalena (2016, p. 160), tem-se algumas premissas: (i) a linguagem é necessária a todo conhecimento, inclusive pelo discurso científico; (ii) é por ela "que o mundo se desvela"; (iii) é também pela linguagem que o sujeito se

\footnotetext{
${ }^{20}$ Nas palavras de Dworkin (2011, p. 129-139): "But they cannot mean, by the intention of the statute, what the legislators had in mind as they voted. Many legislators do not understand the statutes they vote on, and those who do are as often moved by their own political motives - to please constituents, financial backers, or party leaders - as by any principles or policies that a lawyer might attribute to what they enact."
} 
demonstra; (iv) pratica-se ações pela linguagem (ou seja, supera o caráter constatativo das proposições) e (iv) "a linguagem é capaz de criar novos mundos ao abrir novos caminhos de sentido, visto que nomear e adjetivar é criar".

Reconhecer a imprescindibilidade da atividade interpretativa não significa admitir uma multiplicidade de respostas igualmente verdadeiras, mas a exigência de uma atuação responsável que vise à obtenção de uma solução coerente ao caso em concreto e concatenada às decisões já tomadas no passado, como salienta Dworkin com sua teoria do Direito como integridade. ${ }^{21}$

Por esta perspectiva, decisões do passado devem servir de baliza às decisões do presente e do futuro, por exemplo, uma Administração que incentive seus servidores ao aperfeiçoamento em determinadas áreas, por tê-las considerado correlatas as suas atividades, até mesmo com a concessão de auxílio financeiro ou de outra natureza para sua realização, não pode inadmitir a compatibilidade de tais ramos do conhecimento caso venha a instituir um plano de carreira baseado na formação e no aperfeiçoamento técnico. Neste caso, a concessão da progressão fundada na correlação das formações complementares não deve ficar dependente de seu arbítrio ou do modo que formule seu juízo de conveniência e oportunidade. A questão fica ainda mais complexa se este plano de carreira exigir a correlação e as áreas compatíveis nunca sejam expressamente especificadas por ato decorrente do poder regulamentar; a Administração não poderá negar sua análise ou exarar uma resposta negativa diante da aparente ausência de regulamentação, mas deverá estabelecer um exame integrado que conjugue a nova formação, o detalhamento das atividades do cargo ocupado e até mesmo o eventual incentivo dado pela própria instituição.

Para autores como Georges Abboud e José Emílio Medauar Ommati, inexistiria espaço ao agir discricionário, afinal, a atuação da Administração Pública está atrelada ao ordenamento jurídico como um todo, incluindo os princípios, e vinculada ao corolário do Estado Democrático de Direito. A partir desta perspectiva, outras objeções acabam por emergir: (i) a faceta antidemocrática da discricionariedade; (ii) a utilização arbitrária dos princípios; (ii) a exigência da resposta correta.

Não obstante a democracia também seja um conceito interpretativo árduo ao Direito, a admissão da prática discricionária, na condição de esfera de liberdade concedida ao administrador, representa um esvaziamento dos limites impostos por meio da ideia de Estado de Direito e, particularmente, à decisão de cunho democrático.

A democracia, em grande medida, pressupõe em sua legitimação a participação simétrica dos cidadãos, ${ }^{22}$ ou seja, as decisões deixam de ser mera imposição, mas são resultado da abertura participativa aos cidadãos (e também aos seus representantes) e a efetivação de sua autodeterminação, muito mais eficaz no âmbito do processo deliberativo político e legiferante do que no momento da concretização das disposições legais pela Administração Pública.

Admitir que o Direito delegue para o administrador escolhas que ficam ao seu alvitre, partindo da definição de princípios em uma concepção teleológica, em que estes convertem-se em mandados de otimização que possuem o condão de abrir a interpretação do direito e abrir o leque de possíveis resposta, apresenta-se claramente antidemocrático. Não é possível que se realize uma interpretação do direito em que a democracia, de forma democrática, delegue a definição do direito para instrumentos não democráticos, o que é o mesmo que dizer que se escolhe democraticamente não ser mais democrático (MADALENA, 2016, p. 211).

\footnotetext{
${ }^{21} \mathrm{O}$ Direito deve ser entendido como um romance em cadeia, em que a autoridade, especialmente o juiz, deve construir uma narrativa sequencial e contínua, como capítulos de um mesmo romance escrito por diferentes autores, ou seja, cada autor, no momento em que for escrever seu capítulo, deve interpretar e compreender as pretensões da prática dos capítulos anteriores e não simplesmente dar uma nova direção à história sem considerar sua linearidade. Ou seja, o Direito passa a ser visto como uma prática social e argumentativa. Cf. DWORKIN, Ronald. Uma questão de princípio. São Paulo: Martins Fontes, 2001.

22 Para Habermas (2007, p. 137), este substrato da democracia pressupõe que os cidadãos se entendem como destinatários e autores da lei, "devem respeitar-se reciprocamente como membros de sua respectiva comunidade política, dotados de iguais direitos [...]".
} 


\section{Debate}

De acordo com o já exposto, há na doutrina quem considere a omissão legislativa e o substrato dos princípios responsáveis pelo afloramento da discricionariedade administrativa. Os princípios, considerados em alguns momentos como mandatos de otimização, não devem servir de instrumento à ampliação do espaço de decisão do julgador ou mesmo do administrador público, pois a prática tem evidenciado sua utilização, muitas vezes, como verdadeiros trunfos para a aparente justificação de arbitrariedades e do decisionismo. ${ }^{23}$

Na concepção de Madalena (2016, p. 212), os princípios também devem ser entendidos pelo seu caráter deontológico, ou seja, na delimitação de deveres jurídicos, "de modo a estreitar a interpretação do Direito, especificando a resposta correta e não abrindo a possibilidade de diversas respostas serem tidas como aceitáveis, mesmo que umas sejam mais ou outras menos corretas".

Para Luigi Ferrajoli (2012, p. 44), pertencente ao positivismo jurídico, ao atribuir as normas constitucionais à qualidade de princípios ético-políticos, ${ }^{24}$ ou seja, resultado de um processo de argumentação moral e não propriamente "normas rigidamente vinculantes", enfraquece-se a força normativa da Constituição e propicia-se um grande arcabouço principiológico, sem fundamento em seu texto, a serviço da atividade inventiva e até mesmo discricionária do intérprete, especialmente utilizado na atividade jurisdicional. Neste cenário, pelo uso da ponderação, cria-se "uma espécie de bolha terminológica, tão dilatada que chegou às formas mais variadas de esvaziamento e de inaplicação das normas constitucionais, tanto no nível legislativo quanto no nível jurisdicional" (FERRAJOLI, 2012, p. 47).

Logo, a crítica cinge-se à utilização dos princípios como instrumentos retóricos de uma pseudomotivação das decisões no Direito, passíveis a justificar qualquer escolha diante de sua abrangência e ambiguidade, algo próximo, no âmbito administrativo, quando se recorre à ideia de interesse público e de sua supremacia.

Embora as críticas opostas ao principialismo possam atingir também a teoria dworkiniana, tais objeções combinadas ao dever de motivar, constitucionalmente consagrado, culminam no esvaziamento do sentido atribuído ao exercício da discricionariedade pela Administração e em sua sobreposição por um direito fundamental implícito à decisão correta.

Como já tratado anteriormente, a teoria dworkiniana enfatiza a necessidade de a interpretação jurídica atingir um grau de integridade geral que não se confunde com a mera consistência, pois esta elimina tão somente as contradições lógicas entre diferentes formulações, enquanto a coerência manifesta uma concepção única de justiça, em que a formulação pode apoiar-se em uma rede de valores, definindo-se o certo e o errado, o justo e o injusto (GUEST, 2010, p. 46). Logo, a interpretação, no processo deliberativo, não se trata da escolha arbitrária das concepções mais favoráveis às perspectivas subjetivas do intérprete, mas uma atividade rigorosa e ciente do caráter plural dos valores políticos.

Por isso, a escolha responsável pelo intérprete, no caso, o administrador, deve evidenciar como a melhor resposta ao caso concreto e à Constituição e não à própria vontade. Como destaca Lênio Streck (2014, p. 363), baseada na perspectiva hermenêutica não fragmentadora do conhecimento, do processo de interpretação e também de aplicação do Direito, a obtenção das decisões corretas decorre da "integração coerente na prática jurídica, assumindo especial importância à autoridade da tradição (que não aprisiona, mas funciona como condição de possibilidade [...] a tradição não depende da vontade ou da discricionariedade do intérprete".

Para Abboud, Carnio e Oliveira (2015, p. 466-467), a essencialidade de respostas corretas em relação à Constituição conduz a cinco ditames: (i) a conservação da autonomia do Direito diante de argumentos da política, da moral ou mesmo da economia; (ii) a garantia de condições ao controle da interpretação constitucional, embora não exista um método apropriado a assegurar a resposta correta, ou seja, as conclusões não podem resultar da sua mera "consciência"; (iii) propiciar um respeito à "história institucional do Direito", isto

\footnotetext{
${ }^{23}$ Não se pretende aqui avaliar as vantagens e desvantagens do principialismo, mas salientar um desvirtuamento com razoável impacto quanto à respeitabilidade do ordenamento jurídico.

${ }^{24}$ Para Barroso (2001, p. 26): "Princípios contêm, normalmente, uma maior carga valorativa, um fundamento ético, uma decisão política relevante, e indicam uma determinada direção a seguir. Ocorre que, em uma ordem pluralista, existem outros princípios que abrigam decisões, valores ou fundamentos diversos, por vezes contrapostos. A colisão de princípios, portanto, não só é possível, como faz parte da lógica do sistema, que é dialético". Segundo Hesse (1983, p. 47-48), os princípios são responsáveis pela orientação, bem como pela condução das relações/interações, coordenação e valoração das distintas perspectivas que devam ser consideradas para a solução dos problemas jurídicos.
} 
é, à coerência e integridade; (iv) afirmar a fundamentação como um direito fundamental e, por consequência, um dever; (v) oportunizar a avaliação da decisão acerca da sua adequação em relação à Constituição, ou seja, a preservação de sua força normativa.

Nesta visão, não há que se falar em discricionariedade da Administração, mas de um dever responsável à explicitação da resposta mais apropriada ao caso concreto. Logo, a conclusão não é objeto da apreciação conforme a conveniência e a oportunidade, mas da análise rigorosa ao cumprimento da Constituição e de seus preceitos normativos. A melhor solução, neste sentido, não é a conclusão intangível do administrador, mas a resposta motivada e integrada à prática jurídica até então existente e passível de controle pelos cidadãos, inclusive o Judiciário.

Georges Abboud (2011, p. 88-90) vai além, ao atribuir o caráter de direito fundamental à judicial review, ${ }^{25}$ pois este seria essencial ao exercício do direito de ação e na preservação dos direitos fundamentais dos cidadãos. Para tanto, destaca o especial papel do controle difuso de constitucionalidade, como garantia fundamental à análise do caso concreto e de suas particularidades, pois o poder público não está autorizado a violar direitos fundamentais e estes são, inclusive, condição de legitimidade de sua atuação; afinal, "a soberania do Estado está sim limitada pelos fatos e pela história, pelo lugar que o poder político ocupa na sociedade liberal do século XIX" (ABBOUD, 2011, p. 91).

A leitura ${ }^{26}$ do ordenamento jurídico e também a avaliação da atuação do poder público, a partir da Constituição, é complexa e exigente, porém imprescindível. Não significa que se deva recorrer ao que os "pais da Constituição" 27 queriam dizer, mas que "apenas se pode compreender a Constituição e sua indissociável totalidade ao se compreender a tradição em que se encerra, a historicidade que the acompanha" (MADALENA, 2016, p. 167).

Nesse sentido, o protagonismo dos direitos fundamentais e a essencialidade de sua tutela revelam que se trata de um mito a defesa da supremacia do interesse público, afinal, deve-se almejar a supremacia dos direitos fundamentais no dimensionamento do interesse público, pois este "não é direito fundamental, consequentemente, não deve ser utilizado para sopesar outro direito fundamental sob pena de descaracterização da tese de Robert Alexy" (ABBOUD, 2011, p. 99).

Assim, aduz-se uma perspectiva política de sociedade fundamentada em direitos e não meros objetivos a serem alcançados, caso contrário os objetivos justificariam a supressão ou ofensa aos direitos de grupos em nome da utilidade e da máxima felicidade coletiva. Logo, os cidadãos e seus direitos não podem ser utilizados como meios, mas como um fim em si mesmos. A admissão de ofensas aos direitos fundamentais em prol dos benefícios coletivos pode comprometer a própria compreensão de Estado Democrático de Direito e o caráter contramajoritário desses direitos. Haveria, porém, total impossibilidade de impor qualquer restrição aos direitos fundamentais?

Entender a oponibilidade dos direitos fundamentais e sua efetivação até mesmo diante da atuação do poder público não significa a inexistência de limites a tais direitos, mas de uma mudança de foco com o protagonismo dos preceitos constitucionais. Esclarece Georges Abboud (2011, p. 114):

A restrição dos direitos fundamentais pode ser constitucionalmente autorizada e fundamentada em interesse social, mas não no interesse público. Isso ocorre porque a decretação do "interesse público" é um ato arbitrário do Estado que, como Midas, coloca o selo de "público" em tudo o que toca. Nesse cotejo, do ponto de vista prático seria complicado conseguir demonstrar que determinada restrição não atende ao interesse público, contra justamente o instituidor e o principal beneficiário da restrição. Ao contrário, o interesse social demanda

\footnotetext{
${ }^{25}$ Não se trata aqui de uma concepção doutrinária favorável ao ativismo judicial, mas da atribuição da plena efetividade ao controle de constitucionalidade e em defesa dos direitos fundamentais.

${ }^{26}$ No âmbito da teoria constitucional, Hesse (1983, p. 46) destaca a ideia de programa normativo, ou seja, o conteúdo basilar da norma a ser aplicada/efetiva, em que deve ser entendida a relação de sua significação vinculante à resolução do problema.

${ }^{27}$ A tese do originalismo tende a compreender que as autoridades públicas têm o dever de aplicar o Direito segundo a maneira que seus criadores desejavam. Parecem ignorar, todavia, "a distinção entre o que as pessoas querem dizer e aquilo que pretendem - ou esperam, ou desejam, ou temem - que venha a ser resultado do que disserem" (DWORKIN, 2009, p. 187). Esta tese pode parecer útil ao argumentarse que se deve estar atento não propriamente ao que queriam dizer, mas aos objetivos que almejavam. Ainda assim, negligencia-se quanto aos diferentes graus de abstração e concretude englobados por estes ideais e que, inevitavelmente, necessitam de um critério a demonstrar que sua determinação não foi arbitrária, algo que o originalismo parece não ter propriamente estipulado.
} 
justificativa exaustiva por parte do poder público quando determinar a restrição a algum direito fundamental, haja vista que terá que demonstrar, pormenorizadamente, quais os direitos que serão beneficiados com a medida e qual o dispositivo constitucional autorizativo da referida restrição.

Por este entendimento, a atuação discricionária passa a ser vista como inapropriada, pois não existe um espaço de livre decisão ao poder público, mas um dever de atuar responsável com a explicitação dos fundamentos circunstanciais e detalhados, de ordem fática e também jurídica, que acabou por culminar naquela decisão, ou seja, na resposta correta e passível de exame pelo poder Judiciário.

Provavelmente as dificuldades sofridas pelos administrados pela ausência de apropriada fundamentação dos atos do poder público assemelham-se às vivenciadas pelos demandantes no poder Judiciário, pois se os jurisdicionados não sofressem com esta deficiência haveria grande potencial de o artigo 489, do Código de Processo Civil de 2015, sequer existir. Talvez a admissão da insurgência pela devida fundamentação dos atos exarados pela Administração Pública e a imposição de requisitos objetivos a sua concretização, a exemplo do dispositivo anteriormente nominado, levariam a um maior rigor no agir da Administração Pública, inclusive despida do uso performativo da linguagem em atos supostamente discricionários.

\section{CONCLUSÃO}

A doutrina administrativista tem, tradicionalmente, delineado o espaço decisório da Administração Pública a partir dos conceitos de atos vinculados e atos discricionários. Enquanto os primeiros seriam caracterizados pelo cumprimento em concreto da previsão objetivamente traçada pelo ordenamento e pela ausência de espaço de deliberação, posto que tantos os meios como resultados jurídicos almejados estão previstos de maneira incontestável, os segundos garantiriam uma extensão disponível à apreciação, segundo aspectos de conveniência e oportunidade.

Por esta compreensão, aparentemente, haveria uma pluralidade de opções, igualmente válidas, à livre decisão do administrador, todavia as divergências da doutrina expõem algumas fragilidades, entre elas, os riscos:

(i) da blindagem de decisões administrativas arbitrárias ao entender a discricionariedade como uma liberdade e não propriamente como um dever de agir responsável e motivado, passível do controle formal pelo Judiciário;

(ii) da utilização de termos indeterminados, do déficit da técnica legislativa e da abertura valorativa como instrumentos à atuação discricionária;

(iii) do recurso ao arcabouço principiológico como instrumento retórico à motivação rasa de soluções de questões jurídicas complexas no âmbito da Administração Pública.

O estudo pormenorizado das espécies de discricionariedade, baseado nas reflexões de Georges Abboud, retrata diferentes facetas deste instituto e revela as dificuldades na alteração dos paradigmas jurídicos, fato que ocasiona a continuidade do tratamento do fenômeno da interpretação, da decisão administrativa e da aplicação do Direito, como distintos e, até mesmo, autônomos.

O reconhecimento de fragilidades na justificação e teorização da discricionariedade administrativa conduz a três outras objeções:

(i) a primeira, de expressão política, ao realçar a necessidade de abertura democrática, seja ao controle geral e à influência decisória, inferindo-se uma incoerência ao transferir importantes decisões da esfera deliberativa democrática para a seara restrita da escolha unilateral do administrador público;

(ii) a perda da força normativa da Constituição, a partir do momento que são mantidas esferas intangíveis ao controle jurisdicional, por exemplo, do mérito do ato administrativo e pelo uso dos princípios à abertura dos segmentos decisórios ao administrador público;

(iii) a reivindicação da resposta correta, também no âmbito administrativo, em substituição à atividade discricionária, diante dos pressupostos hermenêuticos hodiernos, que exigem uma construção coerente e rigorosa das respostas às questões jurídicas e à concretização de direitos fundamentais. 
Pouco a pouco a temática investigada combinada aos paradigmas da teoria hermenêutica contemporânea acaba por culminar na insustentabilidade do conceito tradicional de discricionariedade administrativa e, consequentemente, na sua substituição pelo pressuposto do agir motivado (e não da livre decisão do administrador), com ampla sujeição ao controle jurisdicional e ao acompanhamento pelo cidadão. Nesse sentido, a Administração Pública passa a comprometer-se com a historicidade de suas decisões, com a efetivação de direitos fundamentais, como da resposta correta, e com a adoção de uma cultura marcada, prioritariamente, pela justificação pública, integrada e coerente de seu agir.

\section{REFERÊNCIAS}

ABBOUD, Georges. Discricionariedade administrativa e judicial: o ato administrativo e a decisão judicial. São Paulo: Revista dos Tribunais, 2014.

ABBOUD, Georges. O mito da supremacia do interesse público sobre o privado: a dimensão constitucional dos direitos fundamentais e os requisitos necessários para se autorizar restrições a direitos fundamentais. Revista dos Tribunais, São Paulo: Revista dos Tribunais, ano 100, v. 907, p. 61-119, maio 2011.

ABBOUD, Georges; CARNIO, Henrique Garbellini; OLIVEIRA, Rafael Tomaz de. Introdução à teoria e à filosofia do direito. 3. ed. rev. atual. e ampl. São Paulo: Revista dos Tribunais, 2015.

ADEODATO, João Maurício. Ética e retórica: para uma teoria da dogmática jurídica. 3. ed. rev. e ampl. São Paulo: Saraiva, 2007. ARAGÃO, Alexandre Santos de. Curso de Direito Administrativo. 2. ed. rev., atual. e ampl. Rio de Janeiro: Forense, 2013.

ARAÚJO, Edmir Netto de. Curso de Direito Administrativo. 5. ed. rev. e atual. São Paulo: Saraiva, 2010.

AUSTIN, John. Lectures of Jurisprudence: or the philosophy of positive law. 4 edition, revised and edited by Robert Campbell. London and Manchester: Sherratt \& Hughes, 1911. Vol. 1.

AUSTIN, John Langshaw. How to do things with words. Great Britain: Oxford University Press, 1962.

BANDEIRA DE MELLO, Celso Antônio. Curso de Direito Administrativo. 25. ed. São Paulo: Malheiros, 2008.

BARROSO, Luís Roberto. Fundamentos teóricos e filosóficos do novo Direito Constitucional Brasileiro. Revista da Emerj, v. 4, n. 15, 2001. Disponível em: http://www.emerj.tjrj.jus.br/revistaemerj_online/edicoes/revista15/revista15_11.pdf. Acesso em: 13 jun. 2016.

CARVALHO FILHO, José dos Santos. Manual de Direito administrativo. 26. ed. rev. ampl. e atual. São Paulo: Atlas, 2013.

CANOTILHO, José Joaquim Gomes. Direito Constitucional e Teoria da Constituição. 3. ed. Coimbra: Almedina, 1999.

DI PIETRO, Maria Sylvia Zanella. Direito Administrativo. 29. ed. Rio de Janeiro: Forense, 2016.

DWORKIN, Ronald. Justice for Hedgehogs. Cambridge: Harvard University Press, 2011.

DWORKIN, Ronald. A raposa e o porco-espinho: justiça e valor. Trad. Marcelo Brandão Cipolla. São Paulo: Martins Fontes, 2014. DWORKIN, Ronald. Domínio da vida: aborto, eutanásia e liberdade individuais. Tradução Jefferson Luiz Camargo. São Paulo: Martins Fontes, 2009.

DWORKIN, Ronald. Uma questão de princípio. São Paulo: Martins Fontes, 2001.

FAORO, Raymundo. Os donos do poder: formação do patronato político brasileiro. 13. ed. São Paulo: Globo, 1998.

FERRAJOLI, Luigi. Constitucionalismo principialista e constitucionalismo garantista. In: FERRAJOLI, Luigi; STRECK, Lenio Luiz; TRINDADE, André Karam. Garantismo, hermenêutica e (neo)constitucionalismo: um debate com Luigi Ferrajoli. Porto Alegre: Livraria do Advogado, 2012. p. 13-56.

FERRAJOLI, Luigi. 13.14. Conflictos entre derechos y ponderación judicial. Discrecionalidad política y discrecionalidad judicial. In: FERRAJOLI, Luigi. Principia iuris: Teoría del derecho y de la democracia. 2. Teoría de la democracia. Madri: Editorial Trotta, 2013. p. 70-75. Vol. 2.

FURTADO, Lucas Rocha. Curso de Direito Administrativo. 4. ed. rev. e atual. Belo Horizonte: Fórum, 2013.

GRAU, Eros Roberto. Por que tenho medo dos juízes (a interpretação/aplicação do Direito e os princípios). 7. ed. São Paulo: Malheiros, 2016.

GUEST, Stephen. Ronald Dworkin. Trad. Luís Carlos Borges. Rio de Janeiro: Elsevier, 2010.

HABERMAS, Jurgen. Entre naturalismo e religião: estudos filosóficos. Trad. Flávio Beno Siebeneicheler. Rio de Janeiro: Tempo Brasileiro, 2007.

HART, Herbert L. A. The Concept of law. Second edition. Oxford: Clarendon Press, 1994.

HESSE, Konrad. Escritos de Derecho Constitucional. Coleccion “Estudios Constitucionales". Madrid: Centro de Estudios Constitucionales, 1983.

HOBBES, Thomas. Leviatã ou matéria, forma e poder de um estado eclesiástico e civil. 2. Ed. São Paulo: Abril Cultural, 1979. 
HOLANDA, Sergio Buarque de. Raízes do Brasil. 26. ed. São Paulo: Companhia das Letras, 1995.

JUSTEN FILHO, Marçal. Curso de Direito Administrativo. 9. ed. atual. rev. e ampl. São Paulo: Revista dos Tribunais, 2013.

KELSEN, Hans. Teoria Pura do Direito. Trad. João Baptista Machado. São Paulo: Martins Fontes, 2003.

LOCKE, John. Two Treatises of Government and a Letter Concerning Toleration. Edited and with an Introduction by lan Shapiro. New Haven and London: Yale University Press, 2003.

MADALENA, Luis Henrique. Discricionariedade administrativa e hermenêutica. Coord. Lenio Luiz Streck. Salvador: Juspodivm, 2016.

MARINELA, Fernanda. Direito Administrativo. 5. ed. Niterói: Impetus, 2011.

MARTINS, Argemino Cardoso Moreira. A noção de Administração Pública e os critérios de sua atuação. In: CADEMARTORI, Luiz Henrique Urquhart; DUARTE Francisco Carlos. (org.). Constitucionalismo em debate: uma homenagem aos 30 anos de pesquisa e docência de Sérgio Cademartori. 1. ed. Rio de Janeiro: Lumen Juris, 2014. p. 187-228. V. 2.

MEIRELLES, Hely Lopes. Direito Administrativo Brasileiro. 37. ed. São Paulo: Malheiros, 2011.

OMMATI, José Emílio Medauar. Do ato ao processo administrativo: a crise da ideia e discricionariedade no Direito Administrativo Brasileiro. Revista dos Tribunais, São Paulo: RT, ano 102, v. 930, p. 23-49, abr. 2013.

OLIVEIRA, Manfredo A. de. Reviravolta linguístico-pragmática na filosofia contemporânea. 3. ed. São Paulo: Loyola, 2006.

POSNER, Richard A. Overcoming law. Massachusetts: Harvard University Press, 1997.

POSNER, Richard A. Cómo deciden los jueces. Trad. Victoria Roca Pérez. Madrid; Barcelona; Buenos Aires: Marcial Pons, 2011.

ROBL FILHO, Ilton Norberto; MADALENA, Luis Henrique Braga. Discricionariedade administrativa no Estado Democrático de Direito: algumas notas a partir das teorias do Estado e da Constituição. Revista Jurídica - CCJ, v. 19, n. 38, p. 147-160, jan./abr. 2015. Disponível em: http://proxy.furb.br/ojs/index.php/juridica/article/view/4885. Acesso em: 3 fev. 2016.

SIMIONI, Rafael. Regras, princípios e políticas públicas em Ronald Dworkin: a questão da legitimidade democrática das decisões jurídicas. Revista Direito Mackenzi. v. 5, n. 1, 2011, p. 203-218. Disponível em: http://editorarevistas.mackenzie.br/index. $\mathrm{php/rmd/article/view/4756/3658.} \mathrm{Acesso} \mathrm{em:} \mathrm{10} \mathrm{fev.} 2017$.

STRECK, Lenio Luiz. Verdade e consenso: constituição, hermenêutica e teorias discursivas. 5. ed. rev., mod. e ampl. São Paulo: Saraiva, 2014. 